\title{
THE INTERNATIONAL CRIMINAL COURT: ASSESSING THE JURISDICTIONAL LOOPHOLES IN THE ROME STATUTE
}

\author{
MELISSA K. MARLER
}

\section{INTRODUCTION}

Beginning in June of 1998, representatives from most of the world's nations met at a conference in Rome to finalize a statute creating an international criminal court. Amid much controversy, the members of the conference finally adopted such a statute, with 120 countries voting in favor of it, seven against it, and twenty-one abstaining. ${ }^{1}$ The International Criminal Court ("ICC") will come into existence once sixty nations ratify the treaty. ${ }^{2}$ During negotiations, some of the most controversial issues proved to be those related to the ICC's jurisdiction. This Note will explore some of those issues.

In particular, the Note concentrates on the jurisdictional restrictions included in Article 12 of the statute and the "opt-out" of jurisdiction over war crimes embodied in Article 124. Part I traces the history of international criminal prosecutions up to the adoption of the Rome Statute. Part II outlines the provisions of the Rome Statute that are relevant to this Note. Part III analyzes the probable consequences of Article 12's jurisdictional provisions and Article 124's "opt-out" provision for war crimes.

The Note concludes that, while it is unfortunate that the custodial state was not included under Article 12 as one through which the

1. See Xavier Baron, Statute for War Crimes Court Adopted, AGENCE FrAnCE-PRESSE, July 18, 1998, available in 1998 WL 2323165.

2. See Final Act of the U.N. Diplomatic Conference of Plenipotentiaries on the Establishment of an International Criminal Court, July 17, 1998, art. 126, 37 I.L.M. 999 [hereinafter Rome Statute]. To date, 95 countries have signed the statute, and seven have ratified it. The seven ratifying countries are Senegal (Feb. 2, 1999); Trinidad and Tobago (Apr. 6, 1999); San Marino (May 13, 1999); Italy (July 26, 1999); Fiji (Nov. 29, 1999); Ghana (Dec. 20, 1999); and Norway (Feb. 16, 2000). See Rome Statute of the International Criminal Court Ratification Status (visited Dec. 27, 1999) <http://www.un.org/law/icc/statute/status.htm> (on file with the Duke Law Journal) (listing updated information on signatures and ratifications). 
ICC could obtain jurisdiction, in practice this omission will not allow perpetrators of international crimes to escape prosecution altogether, as human rights organizations have argued. In addition, the opportunity that Article 124 provides for a state to opt out of jurisdiction over war crimes for seven years after the statute's entry into force for that state may weaken the ICC to some extent, but it will not prevent as many prosecutions as the human rights organizations fear.

\section{HISTORICAL BACKGROUND}

Although the idea of prosecutions for international crimes is an old one, ${ }^{3}$ actual prosecutions have been relatively rare. There is little incentive for states to prosecute their own nationals for crimes perpetrated against the people of another state, especially one with which they are at war. ${ }^{4}$ In fact, war crimes themselves may help states to prevail in wars, and perpetrators of war crimes are often members of a state's own armed forces. In cases where leaders of oppressive regimes commit international crimes against their own people, there is little possibility of prosecution; the people who are committing the atrocities often control the judicial system. In addition, no permanent framework has ever been in place to prosecute international crimes on an international level. Despite these disincentives and structural difficulties, however, states have banded together to prosecute international crimes in some instances.

\section{A. World War II and Its Aftermath}

After the atrocities committed by the Nazi regime during World War II, the international community was outraged at the extent of the cruelties human beings could perpetrate against each other. Although no international framework existed for prosecuting these

3. See John Dugard, Bridging the Gap Between Human Rights and Humanitarian Law: The Punishment of Offenders, 324 INT'L REV. RED CROss 445, 445-46 (1998) (stating that the first international war crimes trial occurred as early as 1474).

4. See id. at 453 (arguing that the political bases for nonprosecutions, particularly with respect to members of the security or armed forces of a state, result in the poor record of national courts in prosecuting war crimes and other international crimes arising out of armed conflicts); see also Christopher C. Joyner, Arresting Impunity: The Case for Universal Jurisdiction in Bringing War Criminals to Accountability, 59 L. \& CONTEMP. PROBS. 153, 153 (1996):

Since war criminals often operate with the knowledge and assistance of local political and legal authorities, domestic law does little to deter these actors. Prevention and punishment of war crimes thus become legal concerns and moral obligations, not just for those governments in whose territory crimes occurred, but for all states. 
crimes, most international observers felt that Nazi leaders should be punished. ${ }^{5}$ The Nuremberg Tribunal proceeded under the relevant Hague $^{6}$ and early Geneva Conventions, ${ }^{7}$ even though neither "contained explicit penal provisions." " While the Nuremberg trials achieved the purpose of signaling to the world that the behavior of the Nazis was unacceptable, the trials were conducted by the Allies and their basis in international law was unclear. Thus, the trials were open to criticism as a biased reflection of "victors' justice."

In a further reaction to the crimes of Hitler's regime, the four Geneva Conventions of $1949^{10}$ expanded on earlier treaty law to create a vast body of legal provisions governing conduct during wartime. These conventions established the grave breaches system, under which state parties are required to criminalize certain acts and must either prosecute perpetrators of those acts in their own national systems or extradite them to another state that is willing to prosecute them. ${ }^{11}$ However, even with this "unequivocal" obligation to prosecute or extradite, ${ }^{12}$ prosecutions of violators of these international

5. See Matthew Lippman, The Pursuit of Nazi War Criminals in the United States and in Other Anglo-American Legal Systems, 29 CAL. W. INT'L L.J. 1, 8 (1998) ("The Allied Powers repeatedly condemned Nazi atrocities during World War II and warned that those who perpetrated these barbarities would be prosecuted and punished.").

6. See Convention Respecting the Laws and Customs of War on Land, Oct. 18, 1907, 36 Stat. 2277 (Hague Convention IV).

7. See Convention Relative to the Treatment of Prisoners of War, July 27, 1929, 47 Stat. 2021, 118 L.N.T.S. 343 (Geneva Convention III).

8. Theodor Meron, International Criminalization of Internal Atrocities, 89 AM. J. INT'L L. 554, 564 (1995). John Dugard, however, observes that both the Geneva and Hague Conventions "contemplate prosecution and punishment of those individuals who violate their norms." Dugard, supra note 3, at 445.

9. U.N.: Sec-Gen Says Establishment of International Criminal Court Is Gift of Hope to Future Generations, M2 PRESSWIRE, July 21, 1998, available in 1998 WL 14097073.

10. See Geneva Convention Relative to the Protection of Civilian Persons in Time of War, Aug. 12, 1949, 75 U.N.T.S. 287; Geneva Convention Relative to the Treatment of Prisoners of War, Aug. 12, 1949, 75 U.N.T.S. 135; Geneva Convention for the Amelioration of the Condition of Wounded, Sick and Shipwrecked Members of Armed Forces at Sea, Aug. 12, 1949, 75 U.N.T.S. 85; Geneva Convention for the Amelioration of the Condition of the Wounded and Sick in Armed Forces in the Field, Aug. 12, 1949, 75 U.N.T.S. 31. Most states are bound by these conventions. For a list of signatories, see International Committee of the Red Cross, States Parties and Signatories (visited Dec. 5, 1999) <http://www.icrc.org/ihl.nsf/WebNORM? OpenView> (on file with the Duke Law Journal).

11. See Meron, supra note 8, at 564.

12. Id. at 555 . 
norms have been rare, owing to "lack of resources, evidence and, above all, political will." ${ }^{13}$

During and after Nuremberg, many states and nongovernmental organizations began to recognize that a permanent international tribunal would be necessary to deal with such outrages should they occur again in the future. The United Nations commissioned a study as early as 1948 to explore the possibility of establishing a permanent international criminal court. ${ }^{14}$ At the same time, however, the Cold War occupied much of the world's attention, precluding any meaningful progress toward establishing such a court. ${ }^{15}$ Serious violations of humanitarian law continued to occur during this period, but no international regime existed to punish offenders. For example, neither the activities of the Pol Pot regime in Cambodia nor Iraq's use of poison gas against its Kurdish citizens has been punished, either nationally or internationally. ${ }^{16}$

\section{B. War Crimes Prosecutions After the Cold War}

In 1989, with the Cold War coming to a close, the International Law Commission began work on a draft statute for an international criminal court. ${ }^{17}$ The disintegration of the former Yugoslavia and the violations of international humanitarian law that occurred in the process, ${ }^{18}$ as well as the 1994 genocide in Rwanda, ${ }^{19}$ provided dramatic confirmation that an international criminal court was indeed still needed, perhaps more urgently than previously believed. ${ }^{20}$

\footnotetext{
13. Id. at 555-56.

14. See Brigid O'Hara-Forster, Justice Goes Global, Time InT'L, July 27, 1998, at 46.

15. See id.; see also Adam Sage, Nailing War Criminals, TIMES (London), Sept. 1, 1998, at 35 (reporting that the establishment of a "permanent [international] tribunal to prosecute perpetrators of genocide, war crimes and crimes against humanity .... was shelved during the Cold War, resuscitated after the fall of the Berlin Wall and given dynamism after the butchery in Bosnia and Rwanda")

16. See Meron, supra note 8, at 554

17. See O'Hara-Forster, supra note 14, at 46.

18. For a detailed historical description of the disintegration of the former Yugoslavia, see Deborah L. Ungar, The Tadić War Crimes Trial: The First Criminal Conviction Since Nuremberg Exposes the Need for a Permanent War Crimes Tribunal, 20 WHITTIER L. REV. 677, 682-84 (1999).

19. For a description of the Rwandan genocide, see Paul J. Magnarella, Some Milestones and Achievements of the International Criminal Tribunal for Rwanda: The 1998 Kambanda and Andakayesu Cases, 11 FlA. J. INT'L L. 517, 517-20 (1997).

20. See O'Hara-Forster, supra note 14, at 46. ("[W]hat really galvanized the international community was the chaotic disintegration of Yugoslavia and the atrocities that accompanied it.").
} 
1. The Ad Hoc Tribunals. The international community struggled to find a way to deal with the gross violations of humanitarian law that occurred in Rwanda and the former Yugoslavia. No international framework was yet in place to enforce international humanitarian law against the offenders, but most observers recognized that the nations involved could not be left to prosecute the offenders on their own. ${ }^{21}$ As heinous acts such as "mass killings, massive, organized and systematic detention and rape of women, and the continuance of the practice of 'ethnic cleansing', including for the acquisition and the holding of territory," continued in the former Yugoslavia, the United Nations decided to take action to bring the perpetrators to justice. ${ }^{22}$ In 1993, the United Nations Security Council, acting under its broad Chapter VII authority, ${ }^{23}$ created a special international tribunal to prosecute those responsible for serious violations of international humanitarian law in the former Yugoslavia. ${ }^{24}$ After the genocide in Rwanda in early 1994, the United Nations Security Council established a similar international tribunal to prosecute the perpetrators. ${ }^{25}$

2. Assessing the Ad Hoc Tribunals. The very creation of these tribunals represented a significant step forward in the prosecution of international crimes. South African jurist Richard Goldstone, the original chief prosecutor for both international tribunals, described them as "the first real international attempt[s] to enforce international humanitarian law." ${ }^{26}$ Unfortunately, they have also been extremely inefficient. Two years of preparation and negotiation were

21. See Catherine Cisse, The International Tribunals for the Former Yugoslavia and Rwanda: Some Elements of Comparison, 7 TRANSNAT'L L. \& CONTEMP. PROBS. 103, 104 (1997) ("The conflicts in Yugoslavia and Rwanda have revealed ... the inadequacy of the national judicial systems to effectively and impartially punish those responsible for violations of international humanitarian law.").

22. S.C. Res. 827, U.N. SCOR, 48th Sess., 3217th mtg. at 1, U.N. Doc. S/RES/827 (1993) (establishing the International Criminal Tribunal for the former Yugoslavia ("ICTY")).

23. See U.N. Charter arts. 39-51. These articles, entitled "Action With Respect to Threats to the Peace, Breaches of the Peace, and Acts of Aggression," empower the Security Council to "determine the existence of any threat to the peace, breach of the peace, or act of aggression" and "make recommendations, or decide what measures shall be taken ... to maintain or restore international peace and security." $I d$. art. 39.

24. See S.C. Res. 827, supra note 22, at 2. The tribunal was to prosecute violations of international law that occurred between January 1, 1991, and "a date to be determined by the Security Council upon the restoration of peace." Id.

25. See S.C. Res. 955, U.N. SCOR, 49th Sess., 3453rd mtg. at 2, U.N. Doc. S/RES/955 (1994) (establishing the International Criminal Tribunal for Rwanda ("ICTR")).

26. O'Hara-Forster, supra note 14, at 46 (quoting Richard Goldstone). 
needed in order to establish the tribunals. ${ }^{27}$ As valuable as they and their decisions would be as precedent in the enforcement of international humanitarian law, ${ }^{28}$ it became even more obvious that a permanent international court would be necessary to deal with such offenses. Not only could the repetitious and time-consuming process of forming a separate tribunal for each incident be avoided, but smaller-scale incidents that would not by themselves warrant the establishment of special tribunals could be handled. ${ }^{29}$

The problems encountered in obtaining custody over those indicted by the Yugoslav tribunal have demonstrated that it is difficult to prosecute offenders at the international level without some cooperation from their territorial states. ${ }^{30}$ Similarly, although the Rwandan tribunal has made an important contribution to international criminal law by issuing a judgment on genocide, ${ }^{31}$ it is doubtful whether the tribunal will have a real impact in deterring future crimes of the same nature, because it will be unable to try a signifi-

27. See id. (quoting Professor Meron, who explained that one advantage to having a permanent court would be that it would "avoid having to spend six months looking for a prosecutor ... and a year looking for a building").

28. For example, the ICTY has found Anto Furundzija, a former local commander of a Bosnian military group, guilty of war crimes. See Prosecutor v. Furundzija, No. IT-95-17/1-T, 38 I.L.M. 317 (I.C.T.Y. 1999), available in Prosecutor v. Anto Furundzija (visited Jan. 12, 2000) $<$ http://www.un.org/icty/furundzija/trialc2/judgment/main.htm> (on file with the Duke Law Journal). It also has found Dusko Tadić guilty of war crimes. See International Criminal Tribunal for the Former Yugoslavia: Excerpts from Judgment in Prosecutor v. Dusko Tadić, No. IT94-1-T, 36 I.L.M. 908 (I.C.T.Y. 1997). For a complete listing of the ICTY's judgments, see Trial Chambers and Appeals Chamber Judgements (visited Jan. 12, 2000) $<$ http://www.un.org/icty/judgement.htm> (on file with the Duke Law Journal). For a complete listing of the ICTR's judgments, see International Criminal Tribunal for Rwanda (visited Jan. $12,2000)<\mathrm{http}: / /$ www.un.org/ictr.html> (on file with the Duke Law Journal).

29. See O'Hara-Forster, supra note 14, at 46.

30. See, e.g., Kevin Sullivan, Is Time up for Bosnia's Accused? NATO Is Toughening Its Stance Toward War Criminals, 25 of Whom May Be in Serb Republic, CHRISTIAN SCI. MONITOR, Dec. 29, 1998, at 6 (reporting that, of the 29 people under public indictment who were not in custody at the time, 25 were "believed to be at liberty in the Serb Republic").

31. See Press Release AFR/94 L/2895: Rwanda International Criminal Tribunal Pronounces Guilty Verdict in Historic Genocide Trial (Sept. 2, 1998) <http://www.un.org/News/ Press/docs/1998/19980902.afr94.html> (on file with the Duke Law Journal) (announcing the "first-ever judgement by an international court for the crime of genocide," in which the ICTR "found Jean-Paul Akayesu guilty of genocide and crimes against humanity"); see also Press Release AFR/95 L2898: Rwanda Tribunal Hands Down Life Sentence for Crimes of Genocide Committed by Former Rwandan Prime Minister (Sept. 4, 1998) <http://www.un.org/News/Press/docs/1998/19980904.12898.html> (on file with the Duke Law Journal) (reporting a genocide judgment against Jean Kambanda). 
cant number of the tens of thousands of perpetrators of the Rwandan genocide.

These two tribunals significantly affected the eventual development of a statute for a permanent international criminal court. In their early years, they were seen as an experiment whose success or failure would have an enormous impact on the eventual creation of such a court. ${ }^{32}$ Today, despite the tribunals' shortcomings, supporters of an international criminal court claim that the tribunals have proven that international prosecutions for gross violations of international law are workable. Supporters further argue that having a permanent court in place would help to resolve the difficulties the tribunals have experienced. ${ }^{33}$

\section{THE ROME STATUTE}

Against this historical background, a United Nations diplomatic conference was held in Rome in the summer of 1998 to finalize the statute for the permanent International Criminal Court. ${ }^{34}$ As the conference progressed, however, several problems became apparent. Many states, most notably the United States, were concerned that allowing the ICC to exercise powers traditionally reserved to states would negatively impact national sovereignty. ${ }^{35}$ In particular, the ways in which the ICC could obtain jurisdiction and the crimes to

32. See James Podgers, The World Cries for Justice, A.B.A. J., Apr. 1996, at 56 (noting that as of 1996, the tribunals had not yet had much success and suggesting that, if they were not effective, their impact would likely be to discourage rather than to encourage the establishment of an international criminal court).

33. See, e.g., Richard Goldstone, Prosecuting International Crimes, an Inside View, Conference Luncheon Address, 7 TRANSNAT'L L. \& CONTEMP. Probs. 1, 3 (1997) (“[T]he practical experience gained through the work of the two Tribunals... has had, and will continue to have, a great deal of effect on the drafting and establishment of a permanent court as it comes into being."); O'Hara-Forster, supra note 14, at 46 (quoting Deputy Prosecutor Graham Blewitt of the ICTY as saying, "WWe have been a model for the creation of the new court."); David Stoelting, Status Report on the International Criminal Court, 3 HOFsTRA L. \& POL'Y SYMP. 233, 241 (1999) ("[P]rior ad hoc international criminal tribunals have demonstrated the feasibility of criminal law enforcement through international tribunals."); see also O'HaraForster, supra note 14, at 46 (noting that a permanent court would avoid the extra effort involved in establishing ad hoc tribunals).

34. See Baron, supra note 1.

35. In fact, during the Bush administration, the United States attempted to delay the formation of an international criminal court indefinitely. Michael Scharf, a State Department official who handled issues relating to the formation of an international criminal court under President Bush, recalls, "One of my jobs, which I did not enjoy ... was to find ways to stall it forever." O'Hara-Forster, supra note 14, at 46 (quoting Michael Scharf). 
which that jurisdiction would apply were deeply divisive questions. ${ }^{36}$ This part will introduce and examine the statute's major jurisdictional provisions.

\section{A. How the ICC Obtains Jurisdiction}

The conference participants quickly rejected a scheme of universal jurisdiction under which nationals of any state, regardless of whether their state was a party to the treaty, could be tried before the ICC for international crimes. States such as the United States, which feared an overly independent court, clearly could not be persuaded to accept such widespread jurisdiction. ${ }^{37}$ Instead, the United States advocated a much narrower position on the other extreme wherein a state's government would have to consent prior to any prosecution of one of its nationals before the ICC..$^{38}$ It soon became clear that this position also would not succeed because the circumstances in which the ICC could obtain jurisdiction would be rare if such a requirement were imposed, since states usually would prefer to try the person in their own national courts or not at all. ${ }^{39}$

In a last-minute attempt to write some degree of state consent for prosecution of nationals into the statute, the United States and India proposed an amendment that would have limited the requirement for prior state consent to situations involving "acts of officials or agents of a state in the course of official duties acknowledged by the state as such." ${ }^{40}$ Demonstrating increasing frustration with the United States' efforts to weaken the ICC, as well as a commitment to a strong court with or without the support of the United States, the conference participants wholeheartedly rejected the amendment. ${ }^{41}$

\footnotetext{
36. See, e.g., Lawyers Committee for Human Rights, Media Alert: Automatic Jurisdiction, Independent Prosecutor Emerge as Most Contentious Issues in Rome (July 9, 1998) $<\mathrm{http}: / /$ www.lchr.org/icc/rome/romealt2.htm > [hereinafter Automatic Jurisdiction] (on file with the Duke Law Journal).

37. See O'Hara-Forster, supra note 14, at 46 ("The Washington negotiators ... rejected universal jurisdiction.").

38. See Theodor Meron, The Court We Want, WASH. Post, Oct. 13, 1998, at A15.

39. See id.

40. Id. It is unclear how much this limitation would have narrowed the state consent requirements, however, as such acts often will be the basis for prosecutions. See infra note 60 .

41. See, e.g., Coalition for an International Criminal Court, A Court Is Born, 1 ON THE RECORD (July 17, 1998) <http://www.advocacynet.org/cgi-bin/browse.pl?id=icc22.html > [hereinafter A Court is Born] (on file with the Duke Law Journal) (announcing that, with a majority of 113 and 25 abstentions, the committee accepted a Norwegian proposal "that no action be taken" on the proposed U.S. amendments).
} 
The system of jurisdiction upon which the conference finally agreed allows the ICC to exercise jurisdiction over genocide, war crimes, and crimes against humanity. ${ }^{42}$ However, this jurisdiction extends only to cases in which either the state on whose territory the acts in question occurred or the state of which the accused is a national is either a party to the statute or has accepted "the jurisdiction of the Court with respect to the [crime in question]." ${ }^{43}$ For example, if a national of State A commits genocide, a crime against humanity, or a war crime on the territory of State B, then the ICC would be able to exercise jurisdiction over the suspected perpetrator only if either State A or State B were a party to the Rome Statute or had accepted the jurisdiction of the ICC over that specific crime. ${ }^{44}$ Many conference participants supported the inclusion of the state that currently has custody of a suspect as a state through which the ICC could obtain jurisdiction, but this provision was dropped late in the conference in order to garner wider support for the statute. ${ }^{45}$

\section{B. “Opting out” of War Crimes Jurisdiction}

Another hotly debated issue at the conference was whether a state would automatically consent to jurisdiction over the core crimes upon becoming a party to the statute or whether it could opt out of jurisdiction over some of them. ${ }^{46}$ While nearly all participants agreed that jurisdiction over genocide should be automatic, the United States, as well as other "key countries," such as France, argued that states should be allowed to "consent separately" to jurisdiction over war crimes and crimes against humanity. ${ }^{47}$ The United States, for instance, supported a proposal that would have allowed states to opt

42. See Rome Statute, supra note 2, art. 5, 37 I.L.M at 1003-04. A further restriction concerning the exercise of jurisdiction over war crimes was added in Article 124. See id. art. 124, 37 I.L.M. 1068. For a detailed discussion of this provision, see infra Parts II.B., III.B. The statute also provides for ICC jurisdiction over the crime of aggression, but only after that crime has been defined internationally. See Rome Statute, supra note 2, art. 5, 37 I.L.M. at 1003-04.

43. Rome Statute, supra note 2, art. 12,37 I.L.M. at 1010.

44. This provision is possibly subject to Article 124's opt-out provision for jurisdiction over war crimes. See infra Parts II.B, III.B (discussing in detail the opt-out provision).

45. See "Fight to the Finish" on International Court (July 17, 1998) $<$ http://www.hrw.org/hrw/press98/july/icc-fnl1.htm> [hereinafter Fight to the Finish] (on file with the Duke Law Journal) (noting that "previous formulations" of the jurisdictional provisions were "less restrictive" and had been "supported by a large majority of delegations").

46. See Automatic Jurisdiction, supra note 36

47. Id. 
out of jurisdiction over war crimes and crimes against humanity for ten years while still accepting automatic jurisdiction as to genocide. ${ }^{48}$

The statute as adopted allows states to opt out of jurisdiction over war crimes, but not crimes against humanity, and for a period of seven years instead of ten:

Notwithstanding article 12 paragraph 1 , a State, on becoming a party to this Statute, may declare that, for a period of seven years after the entry into force of this Statute for the State concerned, it does not accept the jurisdiction of the Court with respect to the category of crimes referred to in article 8 [war crimes] when a crime is alleged to have been committed by its nationals or on its territory. A declaration under this article may be withdrawn at any time. ${ }^{49}$

This provision was included during a late stage of the negotiations, apparently to ensure that France would support the statute. ${ }^{50}$ France, like the United States, has a large number of soldiers serving in peacekeeping missions throughout the world and has shared the United States' concerns that such peacekeeping forces might be subjected to politically motivated prosecutions for war crimes before the ICC. ${ }^{51}$

48. See U.S. Dep't of State: Daily Press Briefing, M2 Presswire, July 22, 1998, available in 1998 WL 14097590. According to the United States, such a provision would have protected its peacekeeping troops from possibly groundless and politically motivated prosecutions for war crimes and crimes against humanity. The United States claimed that it wanted a chance to "see the court in action" before accepting jurisdiction over war crimes and crimes against humanity. Id.

49. Rome Statute, supra note 2, art. 124, 37 I.L.M. at 1068.

50. See, e.g., LAWYERS COMMITTEE FOR HUMAN Rights, THE ROME TREATY FOR AN INTERNATIONAL CRIMINAL COURT: A BRIEF SUMmARY OF THE MAIN IsSUES 3 (1998) (noting that the opt-out provision was inserted to meet French concerns); A Court Is Born, supra note 41 (stating that the opt-out provision was a "last-minute compromise to France" and that "NGOs feel that it creates a gaping loophole that could make it impossible to arrest major criminals").

51. Not everyone shared these concerns. See Ethirajan Anbarasan, A Decisive Victory, UNESCO COURIER, Oct. 1, 1998, available in 1998 WL 10846839 (quoting William Pace, leader of the NGO coalition that favored creation of an international criminal court, as saying that " $[\mathrm{t}]$ he overwhelming majority of nations which contribute peacekeeping troops did not share the concerns about [prosecution of members of peacekeeping forces for war crimes] expressed by France and the U.S.”). 


\section{FEARS OF HUMAN RIGHTS ORGANIZATIONS: WILL PERPETRATORS OF INTERNATIONAL CRIMES GO UNPUNISHED?}

Many human rights organizations argue that the provisions of the Rome Statute do not do enough to ensure that perpetrators of international crimes will be punished. The exclusion of the custodial state as a basis for jurisdiction and the inclusion of the opt-out clause have caused particular concern. Many organizations worry that the exclusion of the custodial state as a basis for the ICC's exercise of jurisdiction will allow international criminals to travel freely, ${ }^{52}$ and one critic has referred to the opt-out provision as a "licence to kill for seven years." "53

This part will explore the concerns generated by both of these provisions. First, it will examine the probable consequences of the exclusion of the custodial state as a basis for ICC jurisdiction, concluding that, while an ideal court would include the custodial state, its exclusion will not in practice allow international criminals to travel freely. Next, this part will examine the probable consequences of the opt-out provision for war crimes in several possible scenarios and will conclude that it will not lead to total impunity for war criminals.

\section{A. Exclusion of the Custodial State as a Basis for Jurisdiction}

The exclusion of the custodial state as a state through which the ICC can obtain jurisdiction has been attacked widely by human rights organizations. Jelena Pejic, head of the Lawyers Committee for $\mathrm{Hu}$ man Rights delegation to the Rome Conference, complained that "[t]he proposal would give criminals a get-out-of-jail-free card." Richard Dicker, leader of the International Criminal Court Campaign of Human Rights Watch, stated, "This court gives a passport to traveling tyrants." ${ }^{55}$ Dicker's statement evidences his belief that the statute's jurisdictional provision would allow human rights violators to travel freely without the worry of being brought before the ICC to

52. See infra notes 54-55 and accompanying text.

53. Sage, supra note 15, at 35 (quoting Denis Robiliard, President of Amnesty International in France).

54. Lawyers Committee for Human Rights, Media Alert: Lawyers Committee Denounces Jurisdiction Provisions of ICC Proposal (July 17, 1998) <http://www.lchr.org/icc/rome/

romealt717.htm> [hereinafter Lawyers Committee Denounces] (on file with the Duke Law Journal).

55. Fight to the Finish, supra note 45. 
answer for their crimes. ${ }^{56} \mathrm{He}$ argues that even if the suspects cannot be brought before the ICC if they remain at home (because their states are not parties to the statute, for example), they should at least be subjected to the ICC's jurisdiction if and when they venture out of the safe havens of their home states.

In addition, Jerry Fowler, legislative counsel for the Lawyers Committee for Human Rights, argues that excluding the custodial state was not necessary under international law. ${ }^{58}$ Because international law already allows individual states to try perpetrators of genocide, war crimes, and crimes against humanity under the principle of universal jurisdiction, "there surely is no bar to a group of states joining together to set up a court that does the same thing."

56. See id.

57. See id.

58. See Lawyers Committee for Human Rights, Media Alert: Lawyers Committee Responds to Congressional Critique of ICC: International Criminal Court Serves U.S. Interests, Will Save American Lives (July 23, 1998) <http://www.lchr.org/media/icc723.htm> [hereinafter Lawyers Committee Responds] (on file with the Duke Law Journal) (quoting Jerry Fowler as saying that "[i]f individual states can exercise ... universal jurisdiction, there surely is no bar to a group of states joining together to set up a court that does the same thing").

59. Under the principle of universal jurisdiction, all states have jurisdiction over certain crimes seen as serious violations of international law, regardless of where these crimes occur or the nationalities of the perpetrators and victims. The theory behind this principle is that all states have a common interest in prosecuting such serious violations of international law. See Kenneth C. Randall, Universal Jurisdiction Under International Law, 66 TEX. L. REV. 785, 788 (1988) ("[T]he universality principle assumes that every state has an interest in exercising jurisdiction to combat egregious offenses that states universally have condemned."). Under customary international law, genocide, war crimes, and crimes against humanity are all subject to universal jurisdiction. See Steven R. Ratner, New Democracies, Old Atrocities: An Inquiry in International Law, 87 GEO. L.J. 707, 715 (1999). For examples of state recognition and use of the principle of universal jurisdiction, see infra notes 62-63.

In fact, the Genocide Convention imposes an obligation on states to search for suspected perpetrators of genocide thought to be within their territories. When the suspects are found, the Genocide Convention imposes a further obligation either to prosecute them within the national system or to extradite them to another state for prosecution. See Convention on the Prevention and Punishment of the Crime of Genocide, Dec. 9, 1948, arts. I, VI-VII, 78 U.N.T.S. 277, 280-82 [hereinafter Genocide Convention].

60. Lawyers Committee Responds, supra note 58. But see Madeline Morris, High Crimes and Misconceptions: The ICC and Nonparty States 26-28 (Oct. 15, 1999) (unpublished manuscript, on file with the author). Professor Morris argues that an international court's exercise of jurisdiction would "have very different implications" than would a state's exercise of universal jurisdiction, so it is not necessarily true that universal jurisdiction is delegable to an international tribunal. Id. at 26. In particular, Professor Morris argues that, while the ICC will not prosecute states as such, official acts undertaken in compliance with state policy will often form the basis for prosecutions. Professor Morris contends that bilateral negotiation may be preferable to third-party adjudication in such cases. An international court would also have more power than would a national court to "create law" in a previously unsettled area, and this new 
1. Does the Exclusion of the Custodial State Really Allow Criminals to Travel Freely? Despite the concerns of these human rights organizations, the exclusion of custodial state jurisdiction will not necessarily provide a "free ticket" to international criminals. As mentioned above, individual states still can try those accused of war crimes in their own domestic courts under universal jurisdiction. ${ }^{61}$ The theory behind universal jurisdiction over such crimes is that some serious international crimes are so harmful as to be offenses against the entire world; states trying such criminals thus are acting on behalf of all states. ${ }^{62}$ Therefore, a state that has custody of a suspected war criminal, even if it cannot turn the suspect over to the ICC, may nonetheless choose to conduct a prosecution in its own national courts. Accordingly, although the criminal may be free from prosecution before the ICC, he may not be free to travel the world without fear of some type of prosecution in some court. ${ }^{63}$

law could not be revised by a legislature. See id. at 28. The Rome Statute does provide that the ICC will declare inadmissible cases in which a state that has jurisdiction prosecutes or investigates and decides not to prosecute. See Rome Statute, supra note 2, art. 17(1)(a)-(b), 37 I.L.M at 1012. Thus, states would not lose the opportunity to negotiate; the perpetrator's national state could negotiate for extradition in order to try the suspect in its own courts. Of course, the national state may not want to do this if it believes the acts were lawful, and a sham prosecution in the national state would not insulate the defendant from prosecution before the ICC. See id.

61. See supra note 59; see also Joyner, supra note 4, at 155 ("International codification and consensus since the Second World War have confirmed war crimes as international criminal acts, thus permitting states to define and punish those extraterritorial crimes wherever, and by whomever, they are committed.").

62. See, e.g., Demjanjuk v. Petrovsky, 776 F.2d 571, 582-83 (6th Cir. 1985) (holding that universal jurisdiction was a valid basis on which to extradite an accused war criminal to Israel), vacated on other grounds, 10 F.3d 338, 356 (6th Cir. 1993); see also RESTATEMENT (THIRD) OF FOREIGN RELATIONS LAW $\$ 404$ (1987) (declaring that "[a] state has jurisdiction to define and prescribe punishment for certain offenses recognized by the community of nations as of universal concern, such as piracy, slave trade, attacks on or hijacking of aircraft, genocide, war crimes, and perhaps certain acts of terrorism, even where" no other basis of jurisdiction exists). Professor Joyner states that Israel's rationale in prosecuting the Eichmann case was that "[e]very state may prosecute violations of modern fundamental norms of international law, especially those relating to war crimes and crimes against humanity." Joyner, supra note 4, at $168 \mathrm{n} .153$ (referring to Attorney Gen. of Israel v. Eichmann, 16 P.D. 2033, 36 I.L.R. 5, 277 (S. Ct. 1962)).

63. Some countries have tried suspected war criminals in their national courts. See, e.g., Polyukovich v. Regina (1992) 172 C.L.R. 501 (Austl.) (holding that Australian courts may prosecute individuals living in Australia for war crimes or crimes against humanity committed on foreign soil); Regina v. Finta [1994] S.C.R. 701 (Can.) (similarly holding that Canadian courts may prosecute individuals living in Canada for war crimes or crimes against humanity committed on foreign soil). However, Finta himself was acquitted, and the Canadian Supreme Court set a high standard for national prosecutions of war crimes and crimes against humanity. See International Decisions, 90 AM. J. INT’L L. 456, 461 (1996) (noting that the Canadian Su- 
In fact, the possibility of such a prosecution may raise the odds that a perpetrator's home state will accept the ICC's jurisdiction over its national. Proceedings before the court will likely be less biased than prosecutions before many national courts. It is unlikely that an international court would conduct an unfair trial or deny a defendant procedural protections, but a state trying a supposed criminal under universal jurisdiction may commit such injustices, especially where there is considerable animosity between the state trying the accused and the accused's home state..$^{64}$

Thus, if an international criminal does venture out of his home state, he may not have the unlimited passport that human rights organizations predict. If he is taken into custody in another state, his national state, even if not a party to the statute, may choose to consent to the ICC's exercising jurisdiction in that particular case when faced with the prospect of having one of its nationals prosecuted in the hostile courts of another state. ${ }^{65}$ And even if the alleged perpetra-

preme Court in the Finta case "established a higher standard of proof for the prosecution of war crimes and crimes against humanity than is recognized at international law," thus making prosecution of World War II crimes "much more difficult and less likely"); Ruth Wedgwood, Pinochet and International Law, 11 PACE INT'L L. REV. 287, 294 (1999) ("The Canadian Supreme Court set an unworkable standard for the proof of international crimes, requiring that the offender must have specific intent to violate international law.... [S]tate of mind is elusive and an offender will rarely have international law provably in mind.").

The events in the Pinochet case also illustrate that, even in the absence of an international court, states will sometimes be willing to exercise universal jurisdiction to bring to justice those accused of gross violations of international law. The British House of Lords ruled that head-of-state immunity did not prevent Pinochet from being extradited to Spain to be tried under universal jurisdiction for atrocities committed while he was Chilean head of state. See Wedgwood, supra, at 291-92. Other European countries in which victims of the Pinochet regime currently reside, including France, Belgium, Luxembourg, Sweden, and Switzerland, were also interested in Pinochet's extradition, for they, too, were "willing to implement universal jurisdiction" to bring Pinochet to justice. Id. at 292.

64. As the state of nationality of the perpetrator, however, these states will still be able to consent to the ICC's exercising jurisdiction on a case-by-case basis under Article 12(3) of the Rome Statute. See Rome Statute, supra note 2, art. 12(3), 37 I.L.M. at 1010. The complementarity provisions contained in Article 17 of the statute, which provide that the ICC must determine that a case "being investigated or prosecuted by a State which has jurisdiction over it" is inadmissible, may, however, preclude the ICC from exercising jurisdiction if the custodial state has initiated proceedings in its own national courts. Id. art. 17(1)(a), 37 I.L.M. at 1012. Thus, states that insisted on the exclusion of custodial state jurisdiction may well regret their positions in the future. These states could well face the possibility of a prosecution of a national before the national courts of a hostile state that is a party to the statute, a state that could have been made to turn the accused over to the ICC on this basis.

65. See id. Even leaders of so-called rogue regimes, which would presumably never become parties to the statute, may in theory be subjected to the ICC's jurisdiction. Assume that such a leader or former leader travels to another state, which apprehends him and plans to try 
tor's state does not consent to ICC jurisdiction over the crime, universal jurisdiction would allow the perpetrator to be tried in other states' national courts, thus alleviating some concern that he could travel freely. ${ }^{66}$

In fact, most of the criminals who will be able to avoid prosecution before the ICC based on the statute as currently written would be able to do so even if the custodial state were included as a state through which the ICC could obtain jurisdiction. If the custodial state were included, international criminals would likely not venture into states that were parties to the statute. Instead, they would remain at home or limit their travel to states that are not only not parties to the statute, but also are unlikely to prosecute them under universal jurisdiction.

Critics fear that the ICC will be "largely ineffective in dealing with rogue regimes," resulting in leaders "who kill their own people on their own territory" remaining, for the most part, out of reach. ${ }^{67}$

him or extradite him to another country for trial, as in the Pinochet case. Faced with the prospect of a trial in that state's national courts (where procedural guarantees may be lacking and the death penalty may be available), the leader's home state may consent to the ICC's exercising jurisdiction in that case. However, the custodial state may not have to yield to the ICC. See Rome Statute, supra note 2, art. 17(1), 37 I.L.M. at 1012 (listing situations in which the ICC may determine that a case is inadmissible for its jurisdiction, including cases in which a state with jurisdiction is conducting a trial or investigation).

66. Of course, the national courts of the other state do not have to try the perpetrator for war crimes or crimes against humanity. Even though the Genocide Convention does impose an affirmative obligation to prosecute or extradite those suspected of genocide, see Genocide Convention, supra note 59, arts. I, VI-VII, at 280-82, in reality, some states do not comply with this obligation, see Symposium, 1945-1995: Critical Perspectives on the Nuremberg Trials and State Accountability, Panel II, Comparative Analysis of International and National Tribunals, 12 N.Y.L. SCH. J. HUM. RTS. 545, 562 (1996) (stating that "[t]he United States definition [of genocide] nearly guarantees that acts of genocide will not be prosecuted in the United States" and is "so fundamentally inconsistent with international law and the Genocide Convention that it is clear the United States is not complying with its treaty obligations").

Similarly, under the Geneva Conventions, states are obliged to prosecute some war crimes. Since some states fail to comply with these obligations, it seems that some states, perhaps because of a lack of political will or political pressure from abroad, will continue to decline to prosecute those suspected of serious international crimes. See supra text accompanying notes 10-13. If the custodial state had been included as a basis for jurisdiction, it could avoid diplomatic pressure from the suspect's home state by turning the suspect over to the ICC. Presumably, the international court would be less vulnerable to diplomatic pressure from one state. While a trial might be more likely to occur if the ICC could obtain jurisdiction through the custodial state, a trial in some court still may occur. Thus, international criminals will not be confined to home, but neither will they be able to travel freely. They only will be able to travel safely to states they know will not exercise their options to prosecute them under universal jurisdiction.

67. Meron, supra note 38, at A15. 
While this proposition rings true, it would be equally true if the cus- 
every time an atrocity has occurred. ${ }^{73}$ It remains to be seen whether the Security Council will be more likely to act when it may simply refer a situation to an existing court rather than create a new tribunal for each situation. This provision is not an ideal means for the ICC to obtain jurisdiction, because whether to apply international humanitarian law to a given situation should not depend on whether the Security Council can agree to act. ${ }^{74}$ Yet, its possibility lessens the chance of a suspected war criminal's remaining out of the ICC's reach.

\section{B. Opting out of War Crimes Jurisdiction}

The "Transitional Provision," or "opt-out" clause ${ }^{75}$ has also been the subject of much criticism since the statute was adopted. ${ }^{76}$ Human rights organizations have been especially critical of the provision. Richard Dicker, leader of the International Criminal Court Campaign of Human Rights Watch, says of the opt-out provision: "This sends a message to potential war criminals-you've got six-and-a-half years to do the job.... That's not justice. That's nonsense." ${ }^{\text {"77 }}$ Amnesty International has appealed to states to refrain from making optout declarations under Article 124 and has suggested that "the United Nations should not accept troops for its peacekeeping opera-

Charter of the United Nations, the International Criminal Tribunal for the Prosecution of Persons Responsible for Genocide and Other Serious Violations of International Humanitarian Law Committed in the Territory of Rwanda and Rwandan Citizens responsible for genocide and other such violations committed in the territory of neighbouring States, between 1 January 1994 and 31 December 1994 . . . shall function in accordance with the provisions of the present Statute.

73. See, e.g., Meron, supra note 8, at 554 ("The heinous activities of the Pol Pot regime in Cambodia and the use of poison gas by Iraq against its Kurdish population are among the many atrocities left unpunished by either international or national courts.").

74. See id. at 555:

While supporting the Security Council's establishment of international tribunals for Yugoslavia ... and Rwanda, I am concerned about the selectivity involved in a system where the establishment of a tribunal for a given conflict situation depends on whether consensus to apply chapter VII of the U.N. Charter can be obtained. What is needed is a uniform and definite corpus of international humanitarian law that can be applied apolitically to internal atrocities everywhere, and that recognizes the role of all states in the vindication of such law.

75. See Rome Statute, supra note 2, art. 124, 37 I.L.M. at 1068:

Notwithstanding article 12 paragraph 1, a State, on becoming a party to this Statute, may declare that, for a period of seven years after the entry into force of this Statute for the State concerned, it does not accept the jurisdiction of the Court with respect to the category of crimes referred to in article 8 [war crimes] when a crime is alleged to have been committed by its nationals or on its territory. A declaration under this article may be withdrawn at any time.

76. See, e.g., Lawyers Committee Denounces, supra note 54.

77. Fight to the Finish, supra note 45 (quoting Richard Dicker). 
tions from states which refuse to recognize the Court's jurisdiction over war crimes." ${ }^{78}$ Even some intergovernmental organizations disapprove of the provision. In fact, the Standing Committee of the Parliamentary Assembly of the Council of Europe recently adopted a recommendation requesting that its member states not make declarations under Article $124 .^{79}$

The United States is outraged by the opt-out provision as well, but for different reasons. The head of the United States' delegation to the Rome Conference, David Scheffer, interprets the provision as allowing a state whose leadership is willing to commit war crimes to join the treaty and then to opt out of war crimes jurisdiction, thus insulating its leaders from prosecution before the ICC for war crimes for seven years, while a nonparty to the treaty could send soldiers into that state on peacekeeping missions and have them immediately subjected to war crimes prosecutions before the ICC. ${ }^{80}$ In the view of the United States, it is an unacceptable paradox to allow citizens of nations that ratify the agreement and take advantage of the opt-out provision to be immune from war crimes prosecutions for seven years, while allowing citizens of states that do not ratify the agreement to be subjected to war crimes jurisdiction as soon as the ICC comes into existence. ${ }^{81}$

Although many states and nongovernmental organizations have been vocal in their opposition to Article 124's opt-out provision, its precise meaning is not clear from the statute. ${ }^{82}$ Perhaps owing to the

78. Pierre Sané, Appeal by Amnesty International to All States to Ratify the Statute of the International Criminal Court as Soon as Possible (May 13, 1999) <http://www.iccnow.org/html/ ai19990513.html> (on file with the Duke Law Journal) (appeal by Pierre Sané, Secretary General of Amnesty International).

79. See Standing Committee of the Parliamentary Assembly of the Council of Europe, International Criminal Court Recommendation 1408 (1999) < http://www.iccnow.org/html/ pace199905.html> (on file with the Duke Law Journal).

80. See Transcript of Statement by the Ambassador at Large for War Crimes Issues and Head of the U.S. Delegation to the UN Diplomatic Conference on the Establishment of a Permanent International Criminal Court Before the Senate Foreign Relations Committee, Washington, D.C., U.S. Dep't of State Dispatch, Aug. 1, 1998, available in 1998 WL 12885550; U.S. Dep't of State: Daily Press Briefing, supra note 48.

81. See, e.g., Gary Dempsey, Courting Global Disaster, WASH. TIMES, Aug. 4, 1998, at A15 (quoting State Department Spokesman James Rubin as saying, "Never before has a treaty put itself over those who have not been included in it." Rubin further stated, "Paradoxically, the treaty also says the nations that ratify the agreement can opt out of the court's jurisdiction over war crimes for seven years, while citizens of those nations that do not ratify the treaty can be subjected to the court's jurisdiction immediately.").

82. See Mahnoush H. Arsanjani, The Rome Statute of the International Criminal Court, 93 
haste with which it was added to the statute, or perhaps owing to a deliberate desire on the part of the negotiators to leave the article in vague terms, many ambiguities remain in Article 124. It is not at all certain that the article will hamper the ICC's effective operation to the degree that human rights organizations fear. Although many human rights organizations believe that the opt-out provision will allow perpetrators of war crimes to enjoy immunity and kill with impunity, ${ }^{83}$ the prospects for bringing these international criminals to justice are not as bleak as the human rights organizations suggest. While Article 124 will make it more difficult for the ICC to obtain jurisdiction in some cases, it will not preclude the ICC from obtaining jurisdiction in most cases. Moreover, the article is not likely to lead to the realization of the United States' concern that citizens of nonparty states will be more likely to face war crimes prosecutions before the ICC than citizens of states that are parties.

1. The Effects of the Opt-out Provision on the ICC's Exercise of Jurisdiction. This section will examine the effects of an opt-out from the ICC's exercise of war crimes jurisdiction in four different types of situations: (1) cases in which perpetrators commit war crimes on the territory of their own states; (2) cases in which perpetrators commit war crimes on the territory of other parties; (3) cases in which perpetrators commit war crimes on the territory of nonparties; and (4) cases in which nationals of nonparties commit war crimes on the territory of parties that have opted out.

a. Cases in which perpetrators commit war crimes on their own national territory. Concerns of human rights organizations that perpetrators of war crimes will go free are most likely to be realized in cases in which offenders commit war crimes within the territory of their own states. If the state in question is a party to the statute, has exercised its option to refuse war crimes jurisdiction, and is still within the opt-out period, the offender would seem to be out of the ICC's reach. If the situation were of particular gravity, however, as in the former Yugoslavia or Rwanda, the United Nations Security Council could conceivably act under its Chapter VII power ${ }^{84}$ to refer

AM. J. INT'L L. 22, 42 (1999) (noting that the statute does not resolve possible conflicts of jurisdiction between two parties).

83. See supra notes $76-78$.

84. See supra note 23 (outlining Chapter VII powers). 
the situation to the ICC. ${ }^{85}$ Unfortunately, it is not clear that the Security Council would usually take such a step. ${ }^{86}$ While the Security Council did act under its Chapter VII powers to create special tribunals for the former Yugoslavia and Rwanda, ${ }^{87}$ numerous other humanitarian law violations did not motivate the Security Council to take action. ${ }^{88}$

The opt-out provision is not likely to be the only reason that criminals who commit war crimes within their own countries will not be brought before the ICC. In fact, the home countries of such criminals will probably not become parties to the statute at all. The Pol Pots and Saddam Husseins of the world are not likely to agree voluntarily to a court that could someday try them. In addition, even if such a state does become a party to the statute as written, ${ }^{89}$ it might not have become a party if opting out had not been a possibility. Thus, even though the opt-out clause might in theory preclude prosecution before the ICC in a case in which a national of a state party that has opted out of war crimes jurisdiction commits war crimes on that state's territory, ${ }^{90}$ in practice there will be few, if any, such cases in which the perpetrator would have been prosecutable before the ICC in any case.

\section{b. Cases in which nationals of a state party commit war crimes}

85. See Rome Statute, supra note 2, art. 13(b), 37 I.L.M. at 1010.

86. See supra notes 22-25 and accompanying text (providing examples of Security Council exercise of its Chapter VII powers).

87. See id.

88. See supra note 73. Moreover, if one of the five permanent members of the Security Council (the United States, the United Kingdom, France, China, and the Russian Federation) were involved in the case, that state's veto power would in all likelihood prevent the case from being referred to the ICC. See U.N. CHARTER art. 27, para. 3 (requiring that decisions of the Security Council on anything other than procedural matters have "the concurring votes of the permanent members").

89. In fact, most such states are unlikely to become parties, since there is no means by which a state can insulate its nationals from prosecution for genocide or crimes against humanity. As discussed below, many of the same crimes that are chargeable as war crimes may also be chargeable as crimes against humanity. See infra Part III.B.2. In addition, the opt-out expires after seven years, at which point the state concerned would either have to withdraw from the statute, see Rome Statute, supra note 2, art. 124, 37 I.L.M. at 1068 ("A State Party may, by written notification addressed to the Secretary-General of the United Nations, withdraw from this Statute. The withdrawal shall take effect one year after the date of receipt of the notification, unless the notification specifies a later date."), or face the possibility of prosecution of its nationals for war crimes. See id. arts. 8, 12, 124, 127, 37 I.L.M. at 1006, 1010, 1068, 1069.

90. Even then, prosecution might be possible because many acts that constitute war crimes also fall under the definition of crimes against humanity. See infra Part III.B.2. 
on the territory of another state party. Assume that State A and State $\mathrm{B}$ are both parties to the Rome Statute and that A has chosen to opt out of jurisdiction over war crimes pursuant to Article 124, while B has not opted out of war crimes jurisdiction. Suppose a national of State A commits war crimes on the territory of State B. The statute is not clear as to whether it would then be possible for the ICC to exercise jurisdiction over the crime pursuant to Article 12(2)(a), under which the ICC has jurisdiction if the state on whose territory the alleged crime occurred is a party. ${ }^{91}$ In other words, the statute does not clarify whether A's decision to opt out has precluded any exercise of jurisdiction by the ICC, or whether it just precludes the ICC from using the fact that $\mathrm{A}$ is a party as the basis for jurisdiction.

In fact, the article permits conflicting readings on this point by providing that a state can "declare that ... it does not accept the jurisdiction of the Court with respect to [war crimes] when a crime is alleged to have been committed by its nationals or on its territory." ${ }^{22}$ This statement could be interpreted to mean that the state exercising this option may prevent the ICC from exercising jurisdiction in all cases in which a crime is allegedly committed by one of its nationals or on its territory. However, the article does not compel this reading. To interpret it in such a way would allow the state that opts out to interfere with the obligations of another state under the statute. If the war crime occurs on the territory of State B, Article 12(2)(a) gives the ICC jurisdiction. Allowing A's opt-out decision to preclude any exercise of jurisdiction by the ICC would thus, in effect, allow A's decision to overrule B's. Though B would have decided by ratifying the statute that the ICC would have jurisdiction over any war crimes committed by B's nationals or on B's territory, A's opt-out, if interpreted in this broad way, would mean that even though B had accepted the provisions of a treaty, the treaty could not become fully effective for B because of a choice made by A. While A's opt-out decision can prevent it from being the "hook" on which the ICC hangs

91. See Rome Statute, supra note 2, art. 12(2)(a), 37 I.L.M. at 1010; see also Arsanjani, supra note 82 , at 42 :

$[\mathrm{T}]$ here may be situations in which a conflict of jurisdiction may arise as between two states parties in relation to war crimes. For example, the territorial state has consented to the court's jurisdiction unconditionally, while the state of nationality of the accused has opted out of the court's jurisdiction over war crimes for seven years. The statute is silent on the interpretation of Article 12 on the jurisdiction of the court in the event of such a conflict.

92. Rome Statute, supra note 2, art. 124, 37 I.L.M. at 1068. 
its jurisdiction, if there is another hook available to the court, A should not be seen as having the unilateral power to stop the ICC from exercising jurisdiction. ${ }^{93}$

c. Cases in which perpetrators commit crimes on the territory of nonparties. Where a party's national is suspected of committing a war crime on the territory of a nonparty, the fact that the party has opted out of war crimes jurisdiction can make it more difficult, but by no means impossible, for the ICC to obtain jurisdiction, even absent Security Council action. In short, the fact that a state has opted out of war crimes jurisdiction may not necessarily mean that the perpetrator has a "licence to kill."

For example, assume State A is a party to the Rome Statute and has opted out of jurisdiction over war crimes, while State C is not a party to the statute. Suppose that a national of State A commits war crimes on the territory of State C. The ICC cannot obtain jurisdiction under Article 12(2)(b), which grants it jurisdiction when the accused's state is a party to the statute, because that state (i.e., State A) has opted out of war crimes jurisdiction under the statute. However, the ICC can still obtain jurisdiction under Article 12(2)(a), in conjunction with Article 12(3), which allows a state to consent to jurisdiction with respect to a specific crime. ${ }^{95}$ State $\mathrm{C}$, the nonparty territorial state, thus could accept the ICC's jurisdiction in this particular case. ${ }^{96}$

Moreover, even if State C does not consent to the ICC's exercising jurisdiction over the crime, the perpetrator may not necessarily go free. Belligerent states have long had the right to prosecute members of enemy armed forces for war crimes. ${ }^{97}$ In addition, within this

93. Similar analysis would apply if the territorial state had opted out of war crimes jurisdiction, while the state of nationality had not.

94. Sage, supra note 15, at 35. For further criticism of the opt-out provision, see Fight to the Finish, supra note 45.

95. See Rome Statute, supra note 2, art. 12(3), 37 I.L.M. at 1010.

96. This acceptance would be valid if, as argued above, Article 124 only prevents the state opting out from being the ICC's jurisdictional hook. Although the opt-out provision in this case does not interfere with another party's obligation under the statute, it would make little sense to interpret Article 124 as only preventing the opt-out state from being the jurisdictional hook in some cases while interpreting it to allow the opt-out state to preclude all ICC jurisdiction in others.

97. See Yoram Dinstein, The Universality Principle and War Crimes, in THE LAW OF ARmed Conflict Into the NeXt Millennium 17, 19 (Michael N. Schmitt \& Leslie C. Green eds., 1998) ("The proposition that belligerent States are accorded an international legal right to 
century, it has become settled in customary international law ${ }^{98}$ that universal jurisdiction applies to war crimes. ${ }^{99}$ Thus, the principle of universal jurisdiction allows any state, not just a belligerent, to prosecute any war criminal without regard to "the geographic, temporal, or national dimensions of the offense." 100 Therefore, if State C can obtain custody of the suspected war criminal, it has the authority to prosecute him in its national courts. In fact, any other state that obtains custody of the suspect can prosecute him under universal jurisdiction.

The existence of universal jurisdiction may cause states to think twice about opting out of war crimes jurisdiction. State A may well prefer to have its nationals tried before an international court, rather than before the courts of State C, especially if the alleged war crimes occurred during an armed conflict between State A and State C. ${ }^{101}$ Presumably, the international court would be neutral, while the national courts of State $\mathrm{C}$ might be biased, or perceived as such.

d. Cases in which a national of a nonparty commits a war crime on the territory of a party that has opted out. As discussed earlier, the United States fears that "a known human rights violator could sign the treaty, opt out of war crimes and yet seek to prosecute the United States when its peacekeeping forces seek to enforce peace and security in that particular country." ${ }^{102}$ These concerns appear reasonable, for it would be patently unfair for a state having declared that "it does not accept the jurisdiction of the Court with respect to

prosecute members of the enemy armed forces charged with war crimes has long been doctrinally recognized.").

98. Customary international law refers to international norms that have been developed as a result of states' acting out of a perceived obligation. In other words, the term customary international law refers to "a usage felt by those who follow it to be an obligatory one." J.L. BRIERLY, THE LAW OF NATIONS: AN INTRODUCTION TO THE INTERNATIONAL LAW OF PEACE 60 (5th ed. 1955). For further explanation of this concept, see IAN BROWNLIE, PRINCIPLES OF PUBLIC INTERNATIONAL LAW 3-15 (2d ed. 1973).

99. See Dinstein, supra note 97, at 20 ("While some scholars continue what may be called a rear-guard action against acceptance of the universality principle as appertaining to war crimes, by now it must be abundantly clear that the issue has been settled in customary intern ational law.").

100. Id.; see also supra notes 59-63 and accompanying text.

101. See supra notes 64-65 and accompanying text.

102. U.S. Dep't of State: Daily Press Briefing, supra note 48. It is important to remember that the ICC will not be prosecuting states, but individuals. People who have committed violations of international law are international criminals, and some argue that they thereby lose, or at least should lose, the protection of their states. See A Court Is Born, supra note 41. 
[war crimes] when a crime is alleged to have been committed by its national or on its territory" "103 to be able to invoke the statute at its pleasure. ${ }^{104}$ If a state has opted out of war crimes jurisdiction, it cannot very well insist that the ICC selectively invoke the very jurisdiction it has denied in order to prosecute members of the United States armed forces.

Article 124 does allow a state party to withdraw its declaration under the article at any time. ${ }^{105}$ However, if the state withdraws its declaration, it would no longer be providing its own nationals with immunity for their war crimes, and its war criminals would therefore be subject to prosecution before the ICC. A state may make an Article 124 declaration only "on becoming a party to [the] Statute." 106 Thus if a state withdraws its declaration, as it clearly has the right to do, in order to see a specific act prosecuted before the ICC, it may not then reinstate its declaration in order to continue providing its nationals with immunity from war crimes prosecution before the ICC.

Article 12(3) does allow a state to accept the jurisdiction of the ICC for a single crime, but that article applies to "State[s] which [are] not Part[ies] to this Statute," not to state parties that have opted out of certain provisions. ${ }^{107}$ Thus, under a logical interpretation of the statute, the concerns of the United States that a state will be able to subject members of a United States peacekeeping force to war crimes prosecution before the ICC, while retaining immunity from war crimes prosecution for its own citizens, are groundless.

Furthermore, the birth of this international criminal court will not subject United States nationals to prosecution for war crimes in circumstances in which prosecutions could not have occurred previously. As discussed above, ${ }^{108}$ universal jurisdiction over war crimes already exists. Thus, a United States national who commits a war crime abroad can already be prosecuted by that foreign government, or, in

103. Rome Statute, supra note 2, art. 124, 37 I.L.M. at 1068.

104. There is international legal precedent showing that courts may be hostile towards parties seeking to enjoy the best of both worlds. See, e.g., Case of Certain Norwegian Loans (Fr. v. Nor.), 1957 I.C.J. 9, 23-24 (July 6) (holding that, in cases before the International Court of Justice, if one party to a dispute has accepted that court's jurisdiction with a reservation, the other party may invoke that reservation against it under the principle of reciprocity).

105. See Rome Statute, supra note 2, art. 124, 37 I.L.M. at 1068.

106. Id.

107. Id. art. 12, 37 I.L.M. at 1010.

108. See supra text accompanying notes 99-100. 
fact, by the national legal system of any nation in which he is in custody. ${ }^{109}$ Thus, if the foreign government refers the case to the ICC instead of prosecuting it in its own national system, the United States national accused of war crimes may very well be more likely to receive a fair trial. ${ }^{110}$

2. Another Option: The Overlap Between Charges of War Crimes and Crimes Against Humanity. In many cases in which an offender can be charged with war crimes, the offender can also be charged with crimes against humanity. For example, according to the Rome Statute itself, the category "war crimes" includes "willful killing" "when committed as a part of a plan or policy or as part of large-scale commission of such crimes." 112 The category "crimes against humanity" includes "murder" "when committed as part of a widespread or systematic attack directed against any civilian population, with knowledge of the attack."114 Torture is also included under both headings, ${ }^{115}$ as well as numerous other acts. ${ }^{116}$ If a state opts out of jurisdiction over war crimes, a national of that state who has committed a war crime may not escape the jurisdiction of the ICC if the war crime could also be characterized as a crime against humanity, as no opt-out provision exists for crimes against humanity. ${ }^{117}$ International humanitarian law already contains

109. See supra text accompanying notes 97-100.

110. See Douglass W. Cassel, Jr., U.S. Fears Undercut Tribunal, CHI. DAILY L. Bull., Aug. 18,1998 , at 5 ("So what's the problem? Americans who today commit any crime overseas can be prosecuted by the foreign government. The treaty merely permits that same government to agree that the case will be heard by an international court, where Americans will more likely get a fair shake."). However, the ICC might be more immune to diplomatic, political, or economic pressure by the United States not to prosecute its nationals. Even so, if the United States investigates the incident in good faith, the ICC will not go forward. See Rome Statute, supra note 2, art. 17(1)(a)-(b), 37 I.L.M. at 1012. The United States does not have such an assurance in the case of a national being tried before another state's national courts.

111. Rome Statute, supra note 2, art. 8(2)(a)(i), 37 I.L.M at 1006.

112. Id. art. 8(1), 37 I.L.M. at 1006.

113. Id. art. 7(1)(a), 37 I.L.M. at 1004.

114. Id. art. 7(1), 37 I.L.M. at 1004.

115. See id. art. 8(2)(a)(ii), 37 I.L.M. at 1006 (War Crimes); id. art. 7(1)(f), 37 I.L.M. at 1004 (Crimes Against Humanity).

116. For example, "[w]illfully causing great suffering, or serious injury to body or health" is included as a war crime. Id. art. 8(2)(a)(iii), 37 I.L.M. at 1005. "[O]ther acts . . intentionally causing great suffering, or serious injury to body or to mental or physical health," are included as crimes against humanity. Id. art. 7(1)(k), 37 I.L.M. at 1005.

117. See id. art. 124, 37 I.L.M. at 1068 (providing opt-out only for "crimes referred to in article 8 [war crimes]"). 
examples of suspects' being charged with both war crimes and crimes against humanity for essentially the same acts. For example, in the Tadić case before the International Tribunal for the Former Yugoslavia ("ICTY"), Dusko Tadić was charged with both crimes against humanity and "violations of the laws and customs of war" for such acts as rape, ${ }^{118}$ murder, "inhumane acts," treatment" ${ }^{, 121}$ arising out of the same sequence of events.

Some commentators have even suggested that charges of crimes against humanity replace charges of war crimes altogether. ${ }^{122}$ While scholars concede that this merging of the two categories has not yet happened under the current definitions of the crimes, ${ }^{123}$ the ICTY has expanded the application of crimes against humanity in recent years. ${ }^{124}$ The Office of the Prosecutor at the ICTY has "used crimes against humanity charges whenever it has been practicable to do so." 125

The statute does not contain an opt-out provision for crimes against humanity, though many states requested one. Thus, even if a state has opted out of war crimes jurisdiction, the acts in question may still be prosecuted before the ICC if they can be characterized as crimes against humanity. As a result, it is even less likely that war criminals will go free because of the opt-out provision.

118. See Prosecutor v. Tadić, Initial Indictment, No. IT-94-1-T (I.C.T.Y. 1995), reprinted in 34 I.L.M. 1011, 1030 (alleging, in Count 4.3, that "forcible sexual intercourse" constitutes a war crime and, in Count 4.4, that "rape" is a crime against humanity).

119. See id. Count 5.3 (alleging "murder" as a war crime); id. Count 5.4 (alleging "murder" of the same victim as a crime against humanity).

120. Id. Count 5.7 (alleging "inhumane acts" as a crime against humanity).

121. Id. Count 5.6 (alleging "cruel treatment" of the same victim as a war crime).

122. See William J. Fenrick, Should Crimes Against Humanity Replace War Crimes?, 37 COLUM. J. TRANSNAT'L L. 767, 769 (1999) (discussing the views of Professor Leslie Green, a war crimes prosecutor in India in the 1940s, who suggested that charges of crimes against humanity should replaces charges of war crimes (citing L.C. Green, 'Grave Breaches' or Crimes Against Humanity?, 8 U.S.A.F. ACAD. J. LEGAL STUD. 19 (1997-98))).

123. See id. at 780 .

124. See id. (explaining that before the ICTY came into existence, crimes against humanity had only been charged when "the civilian victim group had been under the control of or in the hands of the group with which the perpetrator was linked," such as "in camps, in occupied territory, or in the national territory of the state or organization supporting ... the policy of attacking the civilian group").

125. Id. at 785 . However, Fenrick cautions that the "content of the crimes against humanity concept is as yet too skeletal to provide a satisfactory replacement [for war crimes charges]." Id. 


\section{CONCLUSION}

The Rome Statute of the International Criminal Court is not perfect. Considering the wide disagreement that existed at the beginning of the conference, however, it is impressive that the final document garnered as much support as it did. The statute does have some weaknesses, as will any compromise document, but overall it provides an excellent starting point for the consistent prosecution of international crimes.

Despite its shortcomings, this court will not be as weak as human rights organizations argue. The fact that the custodial state's being a party to the statute does not automatically lead to ICC jurisdiction is unfortunate, but not crippling. Ideally, all war criminals should be tried in front of an international tribunal, but the existence of universal jurisdiction means that a custodial state can always try the suspect in its own national system. Thus, war criminals cannot travel freely without fear of prosecution in some court. Furthermore, if a war criminal does travel to a state that is willing to grant him a safe harbor rather than prosecute him for his crimes, that state may not be a party to the statute anyway, making it irrelevant in many cases that the custodial state is not included.

Undoubtedly, the Article 124 provisions allowing parties to opt out of war crimes jurisdiction will also weaken the ICC to some degree, but this article should not be as paralyzing as human rights organizations anticipate. If another state party is either the territorial or national state in a case, then one state's exercise of the opt-out right should not affect the ICC's ability to obtain jurisdiction. In theory, the opt-out should also not affect the state's other obligations under the treaty, but this may, of course, be a different story in practice. ${ }^{126}$

126. This Note does not analyze in detail the effect an opt-out of war crimes jurisdiction under Article 124 would have on a state's other obligations under the treaty. The treaty is unclear as to whether the opt-out would function as an opt-out of all of the state's treaty obligations with respect to the crimes covered by Article 124 or just as an opt-out of being the instrument through which the ICC obtains jurisdiction. See Rome Statute, supra note 2, art. 124, 37 I.L.M. at 1068. In other words, if the ICC does obtain jurisdiction in another way (such as through the territorial state when the national state has opted out), it is unclear whether the state that has opted out must still comply with other related obligations under the treaty. Article 127 , which permits withdrawal from the statute, directly addresses this issue by declaring that a withdrawing state is not freed from obligations that it incurred before its withdrawal became effective, see id. art. 127, 37 I.L.M. at 1069, but Article 124 is silent on the issue, see id. art. 124, 37 I.L.M. at 1068. There are several obligations under the treaty that might be affected by this determination. For example, Article 59 requires a state party to arrest suspects in its territory if requested to do so. See id. art. 59, 37 I.L.M. at 1034. The statute also includes a 
The opt-out provision's practical consequences will also be reduced to the extent that the category of crimes known as "war crimes" overlaps with the category of crimes known as "crimes against humanity." Opting out as to war crimes will not affect the feasibility of charging an offender with crimes against humanity for many of the same acts. The existence of universal jurisdiction will also ameliorate the effect of a party's choice to opt out. If a war criminal wanders from a home state that has opted out of war crimes jurisdiction into a state that is not willing to tolerate his presence, the state can try the offender under universal jurisdiction, even if that state has no legal basis for turning the criminal over to the ICC. Universal jurisdiction may actually prevent some states from embracing the opt-out provision, or at least persuade some states to withdraw their declarations under the provision in order to move a prosecution from the national courts of another, potentially biased, state to the theoretically impartial ICC.

Moreover, the objections of the United States seem to be based on a misinterpretation of the treaty. Parties will not be able to opt out of war crimes jurisdiction and then send war crimes cases involving United States nationals to the ICC. The treaty will not make possible prosecutions of United States nationals that are not already possible through the exercise of universal jurisdiction. In fact, the effect of the establishment of the ICC would be to move any such prosecutions to a forum that is likely to be more impartial. The fact that soldiers on peacekeeping missions have not yet been subjected to charges of war

"[g]eneral obligation to cooperate," which compels state parties to "cooperate fully with the Court in its investigation and prosecution of crimes within the jurisdiction of the Court." Id. art. 86, 37 I.L.M. at 1051. A state can declare under Article 124 that it "does not accept the jurisdiction of the Court" over war crimes alleged to have been committed on its territory or by its nationals, $i d$. art. 124, 37 I.L.M. at 1068 (emphasis added). Article 86 requires cooperation, however, with respect to "crimes within the jurisdiction of the Court" and makes no mention of exempting a state from cooperation when it does not accept the ICC's jurisdiction. Id. art. 86, 37 I.L.M. at 1034.

This issue could become important in some circumstances. If a national of State A, a party that has exercised its Article 124 option to opt out of war crimes jurisdiction, commits a war crime on the territory of State B, the ICC should be able, as we have already seen, to exe rcise jurisdiction pursuant to Article 12(2)(a). See id. art. 12(2)(a), 37 I.L.M. at 1010. If, however, if the suspect is in State A, and State A refuses to cooperate with the ICC because it does not accept jurisdiction, the ICC could do little to obtain custody of the suspect. Of course, there is no guarantee that even states that have not opted out of war crimes jurisdiction will comply with such obligations; however, the opt-out provisions may give states a somewhat more legitimate basis for failing to do so. Having at least an arguably legitimate basis for a refusal to comply with otherwise clearly binding international obligations may lessen the international embarrassment associated with such a refusal. 
crimes under universal jurisdiction seems to negate the theory that leaders in states that currently have populations of peacekeeping soldiers would wish to bring such charges before an international tribunal, unless the charges were indeed based on more than mere antiAmerican attitudes. Since the ICC would not take the case unless the justice system in the United States refused to do so, ${ }^{127}$ United States worries are extremely difficult to understand. Despite the flaws in the Rome Statute's jurisdictional provisions, the ICC, once it comes into existence, should prove to be a useful mechanism for bringing to justice those accused of gross violations of humanitarian law.

127. See id. art. 17(1)(a)-(b), 37 I.L.M. at 1012 (declaring that the ICC will determine a case to be inadmissible where it is "being investigated or prosecuted by a State which has jurisdiction over it, unless the State is unwilling or unable to carry out the investigation or prosecution," or where the case "has been investigated by a State which has jurisdiction over it and the State has decided not to prosecute... unless the decision resulted from the unwillingness or inability of the State genuinely to prosecute"). 